\title{
Kontrola kapitału przeciw pułapce średniego dochodu
}

\begin{abstract}
Kraje rozwijające się i obecnie znacznie już zaawansowane w rozwoju, do których zalicza się Polska mają niższą produktywność czynników wytwórczych, w tym wydajności pracy. Wśród przyczyn ważne znaczenie ma niekorzystny dla nich podział pracy w światowym łańcuchu tworzenia wartości. Ważną przyczyną takiego stanu w krajach postsocjalistycznych była przyspieszona prywatyzacja, głównie z udziałem kapitału zagranicznego, a także struktura zagranicznych inwestycji bezpośrednich. W gospodarce narodowej dominują zagraniczne korporacje, które lokowały w tych krajach pracochłonne procesy produkcji, korzystając z taniej siły roboczej. Podrzędną rolę miejscowej produkcji wzmocnił proces globalizacji. Mogą one znaleźć się w pułapce średniego rozwoju, a obecnie funkcjonują w swoistej niższej lidze gospodarki światowej. Podrzędna rola miejscowych podwykonawców wynika z tego, że nie partycypują oni we własności kapitałowej firm i tym samym mają mały wpływ na władzę międzynarodowych korporacji. Poprawa ich pozycji wymaga aktywnej polityki państw, w tym również w zakresie kontroli struktury przepływu kapitału w ujęciu brutto.
\end{abstract}

Słowa kluczowe: transformacja, globalizacja, inwestycje zagraniczne, międzynarodowe korporacje, kontrola kapitału, międzynarodowy łańcuch tworzenia wartości.

\section{Wprowadzenie}

Polskiej gospodarce grozi spowolnienie tempa wzrostu z powodu wygasania czynników dających jej przewagę komparatywną w stosunku do wysoko rozwiniętych partnerów gospodarczych i handlowych, ponieważ wystąpią skutki niekorzystnego podziału pracy, który przypadł Polsce w międzynarodowym łańcuchu tworzenia wartości towarów i usług. O korzystnej pozycji zajmowanej w tym łańcuchu przesądza kapitał, który daje władzę w dominujących korporacjach międzynarodowych. Poprawa tej pozycji wymaga zaś bardziej skutecznego zarządzania kapitałem.

Polska, stanowiąca mała gospodarkę otwartą, osiągnęła w ostatnim ćwierćwieczu, po transformacji ustrojowej, wydatny postęp gospodarczy. Wysokie tempo wzrostu ułatwiały znaczne zasoby dobrze wykształconej i taniej siły roboczej, przyuczonej do produkcji w warunkach uprzemysłowienia, w procesie nieefektywnej tzw. industrializacji socjalistycznej. Zasoby ludzkie pozostawały 
dostępne dla inwestorów miejscowych i zagranicznych, w kraju w znacznym stopniu zurbanizowanym. Można dodać, że miało też znaczenie korzystne położenie geograficzne Polski, w bliskim sąsiedztwie Unii Europejskiej.

Transformacja ustrojowa na początku lat 90. ubiegłego wieku przyniosła radykalne zmiany w gospodarce polskiej nazwane "terapią szokową”. Przyśpieszona prywatyzacja w ramach „terapii szokowej” sprawiła, że podstawowe zakłady produkcyjne $\mathrm{z}$ braku kapitału rodzimego zostały przejęte przez kapitał zagraniczny. Stworzone też zostały atrakcyjne warunki dla zachęty do bezpośrednich inwestycji zagranicznych (BIZ). Inwestorzy zagraniczni wykorzystali tę zachętę, tj. przede wszystkim tanią siłę roboczą, przenosząc pracochłonne procesy produkcyjne do Polski. Prywatyzacja była niekiedy w istocie sprzedażą segmentu rynku, prywatyzowane przedsiębiorstwo wkrótce zostawało zamknięte, a jego miejsce na rynku krajowym zajmował zagraniczny producent. Czasem jednak zakład przechodził restrukturyzację i modernizację, stając się wykonawcą produkcji zlecanej przez nowego właściciela. W tej fazie rozwoju polskiej gospodarki dawało to jednak wzrost produktywności, wydajności pracy i w efekcie korzyści obu stronom: zagranicznym właścicielom - zarządcom i krajowym wykonawcom. Był to więc offshoring korzystny dla obu stron. $\mathrm{Z}$ powodu braku rodzimego kapitału alternatywą zagranicznych inwestorów mogłoby być tzw. uwłaszczenie - niestety z realną groźbą oligarchizacji gospodarki, jak u wschodnich sąsiadów kraju.

W łańcuchu tworzenia wartości przedsiębiorstwo znajdowało się na dole łańcucha tej krzywej opisywanego „krzywą uśmiechu”, w którym najwyższą marżę wartości dodanej uzyskują firmy ulokowane na początku i na końcu łańcucha. $\mathrm{Na}$ obu podniesionych jego krańcach tworzą bowiem cenę produktu i wartość dodaną właściciele kapitału, twórcy marki producenta, projektanci, organizatorzy łańcucha kooperacji produkcji, zarządzający tym łańcuchem i specjaliści marketingu. Niżej będą usługi dla biznesu: księgowe. finansowe, prawne, logistyczne inne, a po środku krzywej, najniżej - działalność fabryczna. Działalność najbardziej profitującą, umieszczoną na krańcach krzywej, nazwę skromnie: zarządzaniem.

Niestety owo zarządzanie procesowe nie jest polską specjalnością w międzynarodowym podziale pracy. O tej uprzywilejowanej lokacie decyduje właśnie własność kapitału i dzięki temu władza, a ta należy do akcjonariuszy i podległych im menedżerów zarządzających korporacją, nawet jeśli ci ostatni rekrutują się spośród rezydentów. Kapitał, jak wiadomo, nie ma ojczyzny, natomiast akcjonariusze ją mają lub nawet często sobie ją wybrali w rajach podatkowych.

Rozbudzona aktywność przedsiębiorcza społeczeństwa w nowych warunkach ustrojowych, a jedocześnie znaczny napływ kapitału, prywatyzacja przez wykup 
przedsiębiorstw państwowych przez zagranicznych inwestorów oraz nowe inwestycje bezpośrednie z zagranicy sprawiły, że Polska została włączona gwałtownie w proces globalizacji gospodarki światowej, osiagając ewidentne korzyści, jak też, niestety, została narażona na pewne ograniczenia czy wręcz zagrożenia, które uwidoczniły się z czasem.

Globalizacja, globalne rynki utrwaliły więc tę samą pozycję zarówno dla producentów krajowych, jak i inwestorów zagranicznych inwestujących w Polsce - podrzędne miejsce w łańcuchu tworzenia wartości produktów i usług. Były to nadal role: kooperanta, podwykonawcy czy wykonawcy produktów finalnych, zlecanych przez międzynarodowe korporacje. Nie było to jednak w ówczesnym stanie polskiej gospodarki zupełnie niekorzystne.

Bezpośrednie inwestycje zagraniczne przyczyniły się wydatnie do wzrostu zatrudnienia i wydajności pracy, lecz nie były przełomem w zakresie upowszechnienia nowych technologii, ponieważ stanowiły przeniesienie części procesów produkcyjnych. Ten charakter inwestycji dobrze ilustruje ich wydajność mierzona wartością dodaną według poszczególnych branż, w których te inwestycje były lokowane. Efekty bezpośrednich inwestycji zagranicznych (FDJ) mierzone udziałem w tworzeniu Produktu Krajowego Brutto w Polsce badała platforma wiedzy „Polityka Insight”. Część tych wyników zawiera tabela 1 .

Tabela 1. Udział FDI w wybranych branżach w nakładach i rezultatach

\begin{tabular}{|l|c|c|}
\hline & $\begin{array}{c}\text { Struktura branżowa napływu } \\
\text { inwestycji zagranicznych (FDJ) }\end{array}$ & $\begin{array}{c}\text { Udział branż we wzroście PKB } \\
\text { dzięki tym inwestycją (FDJ) }\end{array}$ \\
\hline $\begin{array}{l}\text { Przetwórstwo } \\
\text { przemysłowe }\end{array}$ & $32 \%$ & $17 \%$ \\
\hline Budownictwo & $4 \%$ & $6 \%$ \\
\hline Handel & $16 \%$ & $19 \%$ \\
\hline Pozostałe usługi & $52 \%$ & $68 \%$ \\
\hline
\end{tabular}

Źródło: Czerniak i Blauth, 2017.

Choć zagraniczne inwestycje przynosiły do Polski nowe technologie, to jednak były one z obszaru produkcji przetwórczej, przynoszącej stosunkowo mały wzrost wartości dodanej w działalności przemysłowej i budowlanej, wyższy natomiast w handlu, a zwłaszcza w pozostałych usługach. Natomiast o wiele ważniejszym rezultatem był ich wpływ na rozszerzenie możliwości eksportu, co miało duże znaczenie dla poprawy bilansu płatniczego kraju.

Otwarcie gospodarki na procesy globalizacji przynosiło także nowe doświadczenia organizacyjne $\mathrm{w}$ dziedzinie międzynarodowych relacji gospodarczych 
i handlowych ${ }^{1}$, a także szeroki dostęp do kapitału, dostęp do rynków zagranicznych i wzrost eksportu. Rosła też wydajność pracy i wynagrodzenia, gospodarka Polski skracała dystans rozwojowy do krajów wyżej rozwiniętych. Zasadność w tych okolicznościach przyjęcia instytucji wykształconych w Europie przez Polskę podkreśla Dani Rodrik (2011). Przeprowadzone reformy i dobry stan finansów państwa pozwoliły również spełnić kryteria przystąpienia Polski do Unii Europejskiej w 2004 roku. Wspólny rynek unijny stał się kolejnym impulsem rozwojowym. Postępował proces konwergencji realnej, wzmacniany dodatkowo przez solidarnościowe fundusze unijne. Kryzys gospodarki światowej z lat 2008-2009 tylko spowolnił tempo wzrostu, lecz nie przerwał procesu konwergencji. Również obecne ożywienie czy wręcz dobra koniunktura w gospodarce światowej pozwalają nadal podtrzymać ten proces lecz - jak się wydaje - nie na długo. Rola podwykonawcy nieuchronnie da o sobie znać. Proces konwergencji realnej ustanie. Kraj może wpaść w pułapkę średniego dochodu. Ten termin, choć powszechnie używany, określający sytuację danego kraju, w przypadku sytuacji polskiej gospodarki nie jest - moim zdaniem - odpowiedni. Lepiej tu skorzystać z terminologii sportowej: kraj pozostaje na trwałe graczem niższej ligi gospodarki światowej, z niewielką szansą awansu do ekstraklasy. Może się rozwijać, lecz nie osiągnie poziomu PKB liczonego na 1 mieszkańca, a zatem i dobrobytu obywateli krajów wysoko rozwiniętych. Główną przyczyną jest właśnie ta niższa produktywność pracy, wynikająca z mniej korzystnego miejsca w łańcuchu tworzenia wartości (GWC). Nie jest to bowiem dobry podział pracy między równymi partnerami, bo też partnerzy nie są równi. Nie sposób tu stosować zasady korzyści komparatywnych Davida Ricardo, ponieważ gospodarka światowa jest odmienna od tej sprzed dwóch wieków. Postulat, by każdy robił to, co potrafi najlepiej i najtaniej przestaje być słuszny w warunkach stwarzanych przez globalizację, gdy wszyscy robią ten sam produkt finalny, wykonując tylko różne czynności w różnych krajach².

1 Rodrik zwraca uwagę na to, że Polska, podobnie jak inne kraje Europy, przeszła podobną drogę historyczną. Naśladowanie instytucji, które zostały w Europie stworzone mogły być przydatne w warunkach polskich (Rodrik, 2011).

2 Np. Francuzi lansują modne sukienki i organizują produkcję, mieszkańcy Azji Wschodniej tkają i szyją, a Polacy prowadzą księgowość, magazynują i transportują. Wszyscy pracują w tym bynajmniej nie najnowocześniejszym sektorze gospodarki, lecz wnoszą różną wartość dodaną, co owocuje różnym wynagrodzeniem i różnym poziomem partycypacji w tworzeniu PKB. 


\section{Pułapka czy druga liga?}

Tempo wzrostu gospodarczego w Polsce jest w dalszym ciągu wyższe niż w sąsiadujących krajach wysokorozwiniętych, a ostatnio osiagga nawet 4-5\% rocznie, gdy u sąsiadów stopa wzrostu jest o połowę niższa. Może powstać pytanie, skąd ta obawa o przyszłość polskiej gospodarki o ustanie procesu konwergencji realnej. Niepokój wynika z kilku powodów.

Zawansowanie w rozwoju gospodarczym Polski sprawia, że niebezpieczeństwo pułapki średniego dochodu jest póki co mało prawdopodobne. Poziom PKB w przeliczeniu na jednego mieszkańca według parytetu siły nabywczej stanowi nieco ponad 50\% PKB najbogatszego sąsiada - Niemiec i około 70\% analogicznego poziomu 19 krajów „starej” Unii Europejskiej. Polsce bliżej do krajów rozwiniętych niż większości emerging markets. W przeglądzie literatury światowej na temat pułapki średniego poziomu rozwoju Andrzej Wojtyna (2016, s. 8) stwierdza, że „definicje 'pułapki' można podzielić na te o charakterze jakościowo-deskryptywnym oraz te o charakterze ilościowym. W przypadku tych pierwszych często zwraca się uwagę na trudności w przesuwaniu się krajów na średnim poziomie rozwoju w górę międzynarodowego łańcucha wartości. W tym ujęciu bariery wzrostu mają przede wszystkim charakter mikroekonomiczny w związku z czym ich przezwyciężenie wymaga zastosowania określonych narzędzi polityki przemysłowej”. W tego typu pułapce, w niższej lidze gospodarki światowej może znaleźć się Polska. W tym przypadku tradycyjna polityka przemysłowa, lub szerzej - sektorowa, już nie wystarczy. Powstaje więc pytanie, czy w poszukiwaniu sposobu przeciwdziałania w przypadku takiej postaci pułapki średniego poziomu rozwoju można wykorzystać metodę Nowej Ekonomii Strukturalnej (NES) sformułowanej przez J.Y. Lina (Lin i Nowak, 2018). Samo promowanie sektorów o wyższej wartości dodanej, w tym przypadku już nie przyniesie pożądanych rezultatów, ponieważ poszczególne sektory, w tym również tego typu, w kraju już istnieją, lecz miejsce krajowych producentów w tych sektorach jest niekorzystne, podrzędne. Wynika to ze struktury własności i wspomnianej funkcji zarządzania łańcuchem tworzenia wartości w poszczególnych korporacjach. W tych warunkach chodzi więc o wykorzystanie instrumentów zarządzania przepływem kapitału, aby uniknąć niebezpieczeństw pozostania na trwałe w „drugiej lidze” krajów zaawansowanych w rozwoju, skazanych na niższą produktywność pracy i tym samym niższą marżę wartości dodanej w przeliczeniu na zatrudnionego. Ten stan to niekorzystny rezultat $\mathrm{w}$ istocie pożądanej, lecz pośpiesznej prywatyzacji i również pożądanych, choć nie zawsze spełniających oczekiwania gospodarzy, zagranicznych inwestycji bezpośrednich (BIZ). 
Pomyślny rozwój gospodarczy partnerów handlowych Polski, zwłaszcza krajów Unii Europejskiej sprzyja wzrostowi gospodarczemu również krajów pozostających w owej niższej lidze gospodarki europejskiej. Krzywa produktywności w kształcie „krzywej uśmiechu” może się nawet wygładzać w kierunku prostej. Po pierwsze - dlatego, że zwiększa się udział w tworzeniu PKB wyżej wycenianych usług w porównaniu z działalnością fabryczną, w tym zwłaszcza usług dla biznesu. Mogą również wzrastać i rzeczywiście wzrastają wynagrodzenia w działalności produkcyjnej oraz w usługach, zarówno w następstwie wzrostu poziomu kwalifikacji pracowników, lepszego wyposażenia technicznego miejsc pracy, jak i w następstwie sytuacji na rynku pracy. Wyczerpują się bowiem zasoby taniej siły roboczej w tym jednak przypadku pojawia się także zagrożenie, o czym niżej.

Po drugie - w polskiej gospodarce dużą rolę odgrywają małe i średnie przedsiębiorstwa w tym również przedsiębiorstwa rodzinne. Przedsiębiorstwa te zarządzane są oczywiście przez miejscowych przedsiębiorców, co powinno sprzyjać wyższej produktywności wynikającej z pozycji własności i władzy. Jednak skala prowadzonej działalności w ramach tych przedsiębiorstw jest niewielka, a więc w rezultacie również i produktywność jest niższa niż w przypadku firm wchodzących w skład wielkich korporacji. Rozwój takich przedsiębiorstw musi jednak sprostać konkurencji na rynku zdominowanym przez wielkie korporacje. Jeśli tego typu przedsiębiorstwa nie zostaną zdominowane przez konkurencję, czy też przez nią wykupione, to w rezultacie ich działalności następować będzie również wygładzenie krzywej produktywności. Z kolei wszystkie inne małe i średnie przedsiębiorstwa wraz z wyczerpywaniem się zasobów siły roboczej będą między sobą konkurować o pozyskanie pracowników, co spowoduje również wzrost kosztów pracy, wymuszając zmiany organizacji pracy i inwestycje na rzecz wzrostu wydajności pracy także w tym sektorze. Takie działania w efekcie łącznym przyczynią się też do wzrostu wartości dodanej. Niestety taki bieg zdarzeń może okazać się nazbyt optymistyczny.

Wzrost wynagrodzeń to utrata ważnego elementu przewagi konkurencyjnej. To przecież niższe koszty pracy sprzyjały przenoszeniu do Polski pracochłonnych procesów produkcji oraz szeregu usług w tym również biznesowych. Międzynarodowe korporacje mogą ten rodzaj działalności przenosić do krajów tańszych rąk do pracy. Tak więc outsourcing, który służył polskiej gospodarce w poprzednim stanie niskich płac i bezrobocia, w początkach budowy gospodarki rynkowej, teraz może stać się zagrożeniem, jeśli pozostawi po sobie pogorszenie pozycji przetargowej pracowników czy wręcz bezrobocie.

Po trzecie - dla krajów rozwijających się oraz krajów znacznie zaawansowanych w rozwoju goszczących jednak w niżej lidze gospodarki światowej poja- 
wia się niestety nowe zagrożenie wynikające z nowej rewolucji przemysłowej nazywanej „Przemysłem Generacji 4.0. Choć postęp techniczny związany z tą generacją jest przyjmowany z entuzjazmem, to jednak kraje, które nie nadążaja za przesuwającą się w górę granicą wysokich technologii mogą wiele stracić. Wynika to nie tylko z następstw w postaci zaniku konwergencji realnej, lecz także może spowodować dywergencję, pogłębienie różnic w poziomie rozwoju (Ryć, 2017). Offshoring procesów produkcji z krajów o wysokich kosztach pracy może zamienić się $\mathrm{w}$ reshoring, ponieważ w wyniku cyfryzacji produkcji, inteligentnych fabryk oszczędzających ludzką pracę i tym samym jej koszty przywraca opłacalność. Powrót przetwórstwa przemysłowego do krajów macierzystych międzynarodowych korporacji spowoduje powstanie poważnych problemów dla krajów słabiej rozwiniętych (Götz, 2018).

Jest więc wystarczająco dużo powodów, aby kraje mniej zaawansowane w rozwoju podjęły wysiłki na rzecz opuszczenia owej drugiej ligi.

\section{Zarządzanie strukturą przepływu kapitału dla pożądanych efektów w skali mikroekonomicznej}

Panuje powszechna opinia, że drogą do osiągnięcia wysokiej produktywności są innowacje i przedsiębiorczość. Innowacje tworzy kapitał ludzki i społeczny, na który składają się też instytucje sprzyjające innowacyjności. Tworzenie kapitału ludzkiego wymaga nakładów finansowych na badania naukowe i kształcenie kadr. Niezbędne jest też publiczne wspieranie inkubacji przedsiębiorczości i aktywna w tej dziedzinie rola państwa.

Protegowanie rozwoju gospodarczego przez państwo sprawdziło się w przeszłości w przypadku krajów dziś wysoko rozwiniętych. Również zdało egzamin w wielu gospodarkach dawniej ubogich zwłaszcza w Azji Wschodniej i Południowo-Wschodniej obecnie wysoko rozwiniętych lub znacznie zaawansowanych w rozwoju. Tego typu protekcjonizm jest wykluczony w przypadku Polski - członka Unii Europejskiej - kraju, który po transformacji ustrojowej wkroczył z sukcesem na drogę liberalnej gospodarki rynkowej, choć jest narażony na przedstawione wcześniej zagrożenie pozostania w statusie podwykonawcy.

Postulat postawienia na innowacje, ich tworzenie, formowanie kapitału ludzkiego i społecznego jest oczywisty. Nakłady kapitałowe na ten cel są uzasadnione. Nie ma jednak gwarancji, że dzięki nim wyrosną w kraju potęgi technologiczne generujące wysoką wartość dodaną. Powodem tego są niesprzyjające warunki „hodowli” takich championów, jakie stwarza wolny rynek, a tym bar- 
dziej wspólny rynek europejski. Można co najwyżej liczyć na odosobnione przypadki, ponieważ swobodny przepływ kapitału i wolny rynek temu nie sprzyjają. Swoją opinię, która odnosi się do typu emerging market, ale także do Polski najbardziej dobitnie wyraził J.S. Stiglitz (2010, s. 258) „Liberalizacja handlu oznaczała, że zagraniczne firmy mogły „wyżynać w pień” raczkujące miejscowe branże, tłamsząc rozwój przedsiębiorczych talentów. Gdy kapitał przepływał swobodnie, przepływ siły roboczej był ograniczony - z wyjątkiem najbardziej utalentowanych jednostek, z których wiele znajdowało dobre zatrudnienie na globalnym rynku pracy”. Te ostre słowa noblisty odnoszą się również do doli wielu inicjatyw i karier wybitnych jednostek w Polsce. Nie są natomiast usprawiedliwieniem dla polskich lamentów nad odpływem zysków za granicę od międzynarodowych korporacji, które zainwestowały w Polsce. Do tego mają prawo i powinniśmy pozostać im życzliwi za to, co uczynili, tworząc miejsca pracy i za to, co pozostawiają w Polsce $\mathrm{w}$ postaci wynagrodzeń pracowniczych $-\mathrm{z}$ reguły wyższych od tych rodzimych w małych i średnich przedsiębiorstwach oraz zapłaconych u nas podatków. Nie znaczy to bynajmniej rezygnacji z osłony i ze wspierania rodzimych konkurentów również za pomocą środków kapitałowych, tym bardziej przez skuteczne zarządzanie strukturą przepływu kapitału. A więc nie chodzi o zmianę reguł gry, lecz o skuteczniejsza grę o wejście przez rodzimy kapitał na pozycję zarządzania w coraz większej części liczących się producentów i świadczeniodawców usług. Wypracowanie metod i narzędzi operowania kapitałem w tym kształtowaniem struktury kapitału w skali mikroekonomicznej wspierającym politykę przemysłową wydaje się zadaniem możliwym w założeniach Nowej Ekonomii Strukturalnej.

W tym miejscu można wskazać kilka kierunków oddziaływania za pomocą środków kapitałowych.

1. Na pierwszym miejscu należy postawić to, co prawie wszyscy badacze uważają za istotne, a mianowicie na nakłady finansowe na wzrost kapitału ludzkiego i społecznego. Chodzi o to by zdolnych ludzi kształcić, a wykształconych nie tracić, badania finansować, lecz ich wyników, które mogą być zaczynem innowacji nie eksportować w surowej postaci. Nie jest to więc zadanie prostego powiększania środków na ten cel, lecz ich przemyślanej struktury zabezpieczającej uzyskanie pożytku z zainwestowanego kapitału. Struktura angażowanych środków winna nie tylko maksymalizować wzrost, lecz także minimalizować ubytek i straty tego kapitału.

2. Należy ostrożnie podchodzić do państwowej „hodowli” championów. Co było możliwe w Azji Wschodniej, nie jest do powtórzenia w Europie Środkowej i we wspólnym rynku. Przykładowo, w Polsce postawienie na elektromobilność w przemyśle samochodów osobowych, bez rodzimych innowacji, nie ma 
praktycznie wielkich szans na wyjście poza wykonawstwo i montaż. Technologicznie zaawansowane komponenty będą zakupywane za granicą nawet wtedy, gdy zagraniczni producenci zechcą je wytwarzać w Polsce. To oni właśnie znajdują się w korzystnej pozycji wnikającej z ich własności i władzy. Nie znaczy to, że podobnych prób nie należy całkowicie wykluczyć, lecz nie można wzorem reguł „starej” Ekonomii Strukturalnej, która m.in. dopuszczała produkcję antyimportową - na nich budować korzystnej pozycji w łańcuchu tworzenia wartości ${ }^{3}$ (Lin i Nowak, 2018).

3. Kontrola struktury dopływu i odpływu kapitału: wspieranie outsursingu do Polski przedsięwzięć innowacyjnych zgłaszających popyt na pracę wykwalifikowaną, dobrze wynagradzaną oraz na usługi dla biznesu. $Z$ rezerwą natomiast trzeba się odnosić do przenoszenia prostej produkcji, jeśli ona nie ułatwia rozwiązywania, np. lokalnych problemów rynku pracy.

4. Udomowienie zagranicznego kapitału przez tworzenie korzystnych warunków dla wprowadzania przez nie nowych technologii, reinwestowania zysków. Co prawda nie można obecnie liczyć na współczesnych Wedli, Moteli czy Bliklich, zagranicznych przedsiębiorców i inwestorów, którzy w Polsce osiedli i od pokoleń prowadzili tu swój biznes. Zapewne za przyczyną choćby większej mobilności społecznej trwała rezydencja zagranicznych współwłaścicieli czy właścicieli jest mniej prawdopodobna.

5. Możliwy jest wykup przez rodzimy kapitał niepubliczny w całości lub też udziałów w zagranicznych przedsiębiorstwach działających w kraju. Nie chodzi tu o repolonizację, czyli wykup przez spółki państwowe, lecz przede wszystkim rodzimy sektor prywatny wraz z jego umocnieniem na rynku kapitałowym.

6. Pogłębienie usług finansowych nie tylko dla małych i średnich przedsiębiorstw oraz poczatkujących producentów, lecz także dla ambitnych przedsięwzięć kapitałowych polskich producentów w kraju i za granicą.

7. Celowy offshoring - Polska dotychczas korzystała i nadal korzysta z przenoszenia do nas produkcji zagranicznych firm. Dziś obawiamy się ich ucieczki do miejsc o tańszej sile roboczej. Jednak stosunkowo mały jest offshoring polskich firm do krajów o niższych kosztach produkcji. Teraz i w przyszłości należy na większą skalę korzystać z tej metody i przenosić mniej wydajną produkcję poza granice naszego kraju. Oczywiście pod warunkiem, że nie grozi to wzrostem bezrobocia. Tego typu działania polskich przedsiębiorców należy mocniej wspierać.

3 Polskie przedsiębiorstwo, które z sukcesem wytwarzało autobusy z napędem elektrycznym, również z sukcesem je eksportowało zostało wystawione na sprzedaż i zapewne trafi w ręce zagranicznych inwestorów. 


\section{Podsumowanie}

Proces dochodzenia do korzystnej pozycji w międzynarodowym łańcuchu tworzenia wartości, za pomocą aktywnej polityki kontroli przepływu kapitału, nie jest bynajmniej pewny ani tym bardziej krótki. Wysiłki w tej dziedzinie należy podejmować, ponieważ pozostawanie kraju w owej niższej lidze gospodarki światowej nie tylko nie satysfakcjonuje społeczeństwa, lecz także jest niebezpieczne. Grozi bowiem wpadnięciem w autentyczną pułapkę średniego poziomu rozwoju.

\section{Bibliografia}

Czerniak, A. i Blauth, K. (2017). Co przyniosty inwestycje zagraniczne. Warszawa: Polityka Insight.

Götz, M. (2018). Przemysł czwartej generacji (przemysł 4.0) a międzynarodowa współpraca gospodarcza. Ekoomista, (4), 385-403.

Lin, Y.J. i Nowak, Z.A. (2018). New structural economics for less advanced countries. Warszawa: Wydawnictwo Wydziału Zarządzania Uniwersytetu Warszawskiego.

Rodrik, D. (2011). Jedna ekonomia wiele recept. Warszawa: Krytyka Polityczna.

Ryć, K. (2017). The expiring real convergence process under conditions of the common market - how to counteract. W: Y.J. Lin, A.Z. Nowak, New structural economics for less advanced countries (s. 69-79). Warszawa: Wydawnictwo Naukowe Wydziału Zarządzania Uniwersytetu Warszawskiego.

Stiglitz, J.E. (2010). Freefall. Warszawa: Polskie Towarzystwo Ekonomiczne.

Wojtyna, A. (2016). Standardowe i niestandardowe działania antykryzysowe. Gospodarka Narodowa, (6). 5-22. 